\title{
腔外科学領域論文の情報科学的分析
}

\section{-1. 主題分析-}

清水文夫・待田順治・林 清広・伊地知 明 - 山崎安一

\section{Analysis of scientific literatures on the oral surgery from the view point of informational science \\ -1. Analysis of the subject-}

Fumio ShImizu • Junji MACHDA - Kiyohiro HAYASHI - Akira IJICHI - Yasuichi YamazAKI

緒

言

今日，世界において流通している学術論文などは年間 数百万件にのぼり，10年間で倍増する傾向にあるといわ れている1).

医学・歯学・薬学に関連した分野での論文数を医学中 央雑誌に掲載された論文数でみると，数年前から年間約 10万編以上と膨大な数であり, かつ経年的増加傾向にあ る。この中で歯学に属するものは年間約 5 千編を越兄， かつ同様の増加傾向を示している．だがこれらの論文の らち，少なくとも口腔領域のものについて組織だった分 析は行われたことがなく2)，多量の論文が野放し状態に されていると煩雑すぎてそれらの適切な活用が著しく困 難になると思われる。

このような眯念から, 待田2) は日本口腔科学会雑誌の 情報科学的特徵を把握し, さらに口腔科学領域の学術論 文を有効かつ円滑に活用する方法について検討すること を目的として，同雑誌の第 1 巻（昭和 27 年）から第 27 巻 （昭和53年）までに掲載された論文を組織だって分析し， その成果を発表している。

そこでわたくしたちはこの目的達成の一環として, 日 本口腔外科学会雑誌の第 1 巻（昭和 30 年）から第 25 巻 （昭和 54 年）までに掲載された論文の主題分析などを行 ったので，その概容を報告する.

$$
\text { 方法 }
$$

\section{1. 分析対象}

日本口腔外科学会雑誌の第 1 巻（昭和 30 年）から第 25

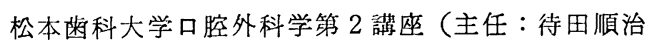
教授)

Second Department of Oral Surgery, Matsumoto Dental College (Chief: Prof. Junji Machida) 受付日：昭和56年 5 月 25 日
巻（昭和54年）までに揭載された学術論文 1,724 編を分 析対象とした。

\section{2. 分析項目}

これらの論文を下記の項目について分析した。

1）主題項目とその論文数

2) 主要主題項目の詳細

3 ）主要主題項目に属する論文数の年代変化

\section{3. 分析方法}

それぞれの論文と 1 対 1 に対応するマークシートカー ドを作製した。このカードには書誌事項の記載に加え て，主題・キーワードのコード，発表年，著者名などを マークした。な和論文の主題は，待田 ${ }^{2)}$ の行った主題分 析を参照しつつ, 疾患の種類・発現部位などから選び, それらをコード化した。主題の重複は可及的回避した。

度数集計には情報検索機（田中精機製 640 I 型）を使 用した。

論文数の年代変化は，全 25 巻を第 $1 \sim 5$ 巻（昭和 $30 \sim$ 34 年), 第 $6 \sim 10$ 巻（昭和 $35 \sim 39$ 年)，第 $11 \sim 15$ 巻（昭和 $40 \sim 44$ 年), 第16 20巻（昭和 $45 \sim 49$ 年), 第 $21 \sim 25$ 巻 （昭和 50 54 年）の 5 期間に分けておの拈のの期間内で の主題ごとの論文の割合として分析した.

\section{結果}

\section{1. 主題項目と論文数}

分析結果は表 1 のと扣りである．良性腫瘍と悪性腫瘍 の論文が王倒的に多く、これらを合計すると総論文数の $31.9 \%$ を占めた。

\section{2. 主要主題項目の詳細}

その結果は表 2 のと㭣りである。良性腫瘍，整胞，顎 骨では症例報告が大部分であるが，悪性腫瘍では基礎的 研究がやや多く (21.4\%) さらに抗生物質ではその半数 （50.6\%）を占めていた。

3. 主要主題項目に属する論文数の年代変化 その結果は表了のと抢りである。どの年代でる良性腫 
表 1 主題項目と論文数

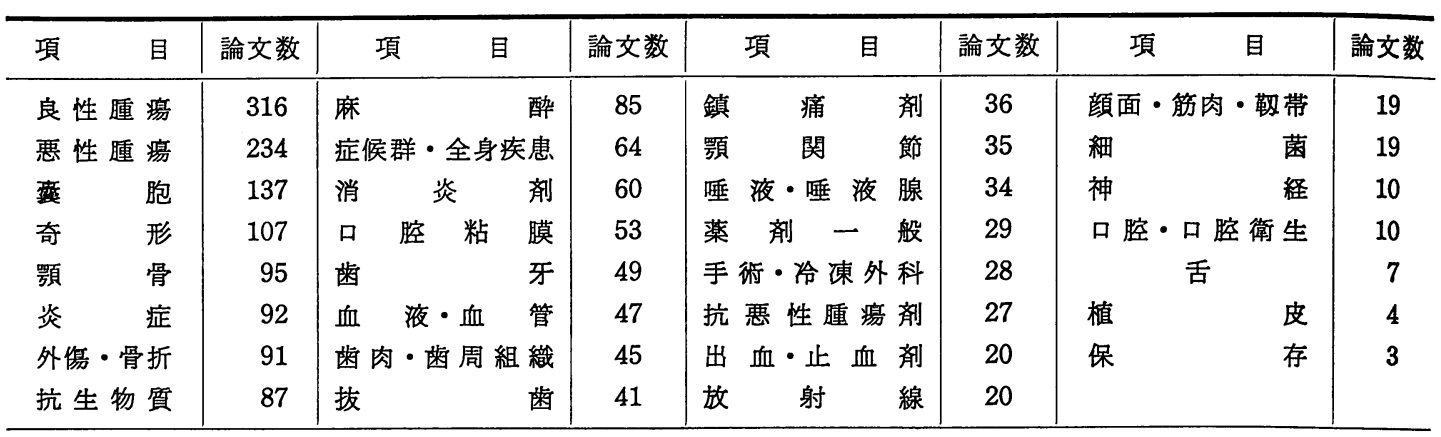

薬凨一般：他の主題項目に含まれない薬凨

表 2 主要主題項目の詳細

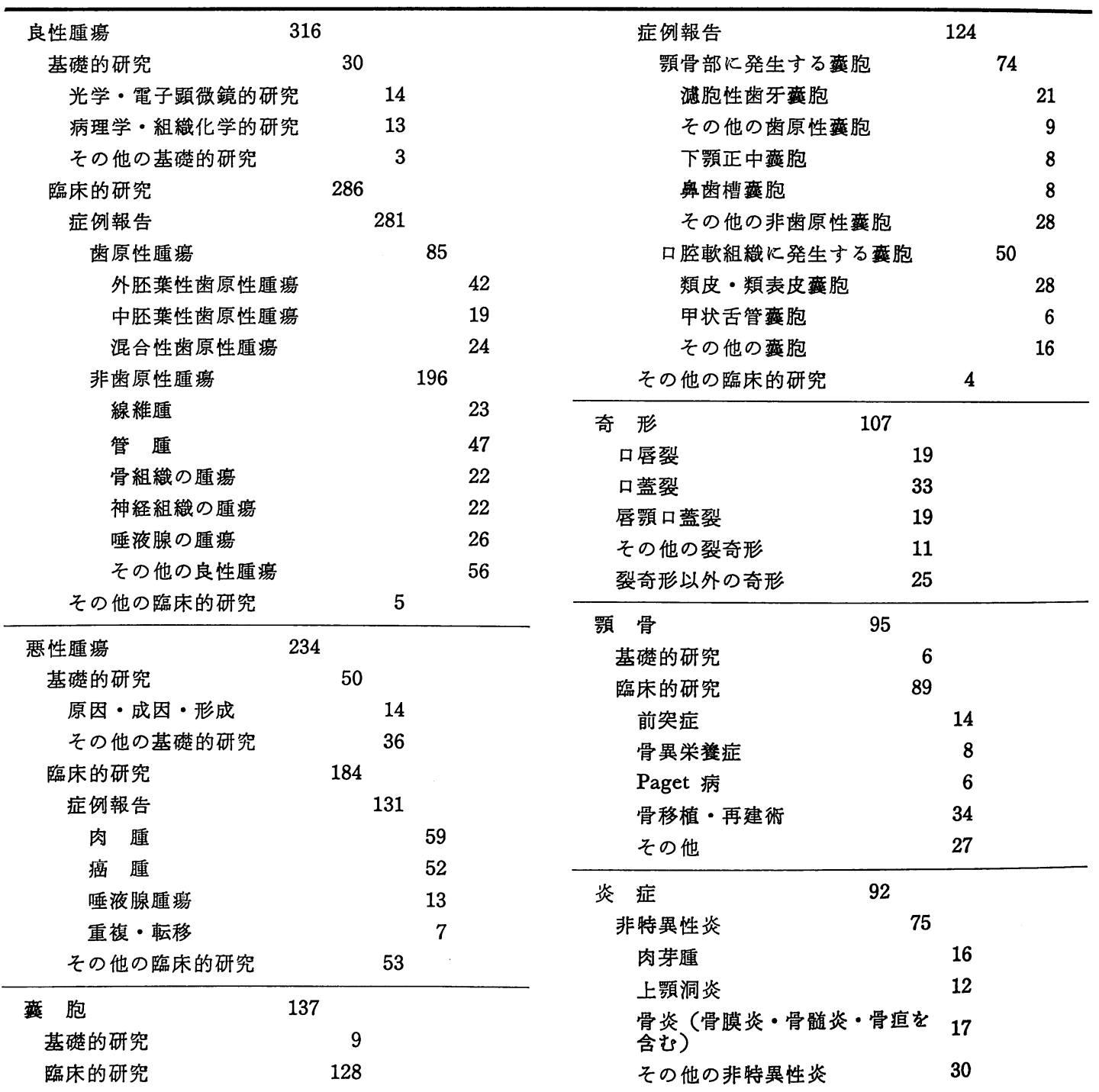


表 2 つづき

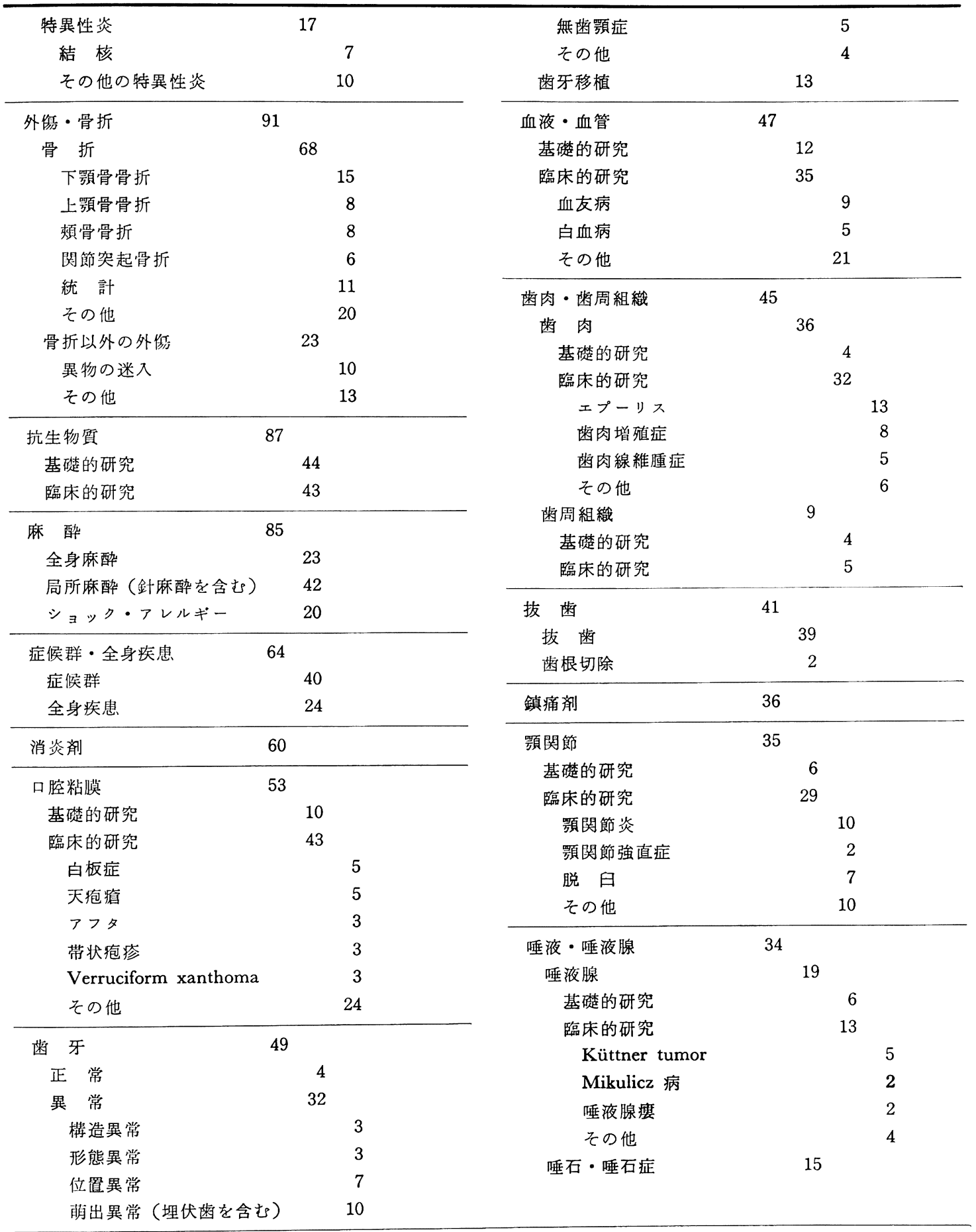


表 3 論交数の年代変化（\%)

\begin{tabular}{|c|c|c|c|c|c|c|c|c|}
\hline \multicolumn{3}{|l|}{ 項目 } & $30 \sim 34$ & $35 \sim 39$ & $40 \sim 44$ & $45 \sim 49$ & $50 \sim 54$ & 計 \\
\hline & 性 & 嫁 & $42(20.0)$ & $35(13.0)$ & $21(14.0)$ & $68(17.2)$ & $150(21.5)$ & $316(18.3)$ \\
\hline 悪 & 性 & 䇠 & $22(10.5)$ & $28(10.4)$ & $16(10.7)$ & $42(10.6)$ & $126(18.0)$ & $234(13.6)$ \\
\hline 菨 & & 胞 & $16(7.6)$ & $15(5.6)$ & $16(10.7)$ & $34(8.6)$ & $56(8.0)$ & $137(7.9)$ \\
\hline 奇 & & 形 & $12(5.7)$ & $17(6.3)$ & $7(4.7)$ & $36(9.1)$ & $35(5.0)$ & $107(6.2)$ \\
\hline 䅡 & & 骨 & $10(4.8)$ & $13(4.8)$ & $10(6.7)$ & $14(3.5)$ & $48(6.9)$ & $95(5.5)$ \\
\hline 炎 & & 症 & $10(4.8)$ & $16(5.9)$ & $8(5.3)$ & $17(4.3)$ & $41(5.9)$ & $92(5.3)$ \\
\hline 外 & 伤・骨 & 折 & $10(4.8)$ & $16(5.9)$ & $7(4.7)$ & $21(5.3)$ & $37(5.3)$ & $91(5.3)$ \\
\hline 抗 & 生 物 & 質 & $8(3.8)$ & $9(3.3)$ & $7(4.7)$ & $51(12.9)$ & $12(1.7)$ & $87(5.0)$ \\
\hline 麻 & & 酔 & $21(10.0)$ & $18(6.7)$ & $12(8.0)$ & $19(4.8)$ & $15(2.1)$ & $85(4.9)$ \\
\hline \multicolumn{3}{|c|}{ 症候群 - 全身疾患 } & $2(1.0)$ & $8(3.0)$ & $5(3.3)$ & $14(3.5)$ & $35(5.0)$ & $64(3.7)$ \\
\hline 消 & 炎 & 剤 & $2(1.0)$ & $17(6.3)$ & $10(6.7)$ & $17(4.3)$ & $14(2.0)$ & $60(3.5)$ \\
\hline 口 & \multirow[t]{2}{*}{ 膑 粘 } & 膜 & $3(1.4)$ & $9(3.3)$ & $7(4.7)$ & $9(2.3)$ & $25(3.6)$ & $53(3.1)$ \\
\hline 歯 & & 牙 & $11(5.2)$ & $20(7.4)$ & $0(0.0)$ & $10(2.5)$ & $8(1.1)$ & $49(2.8)$ \\
\hline 血 & \multicolumn{2}{|c|}{ 液・血 管 } & $5(2.4)$ & $7(2.6)$ & $8(5.3)$ & $9(2.3)$ & $18(2.6)$ & $47(2.7)$ \\
\hline \multicolumn{3}{|c|}{ 歯肉 - 歯 周 組 織 } & $8(3.8)$ & $11(4.1)$ & $1(0.7)$ & $13(3.3)$ & $12(1.7)$ & $45(2.6)$ \\
\hline 抜 & \multicolumn{2}{|c|}{ 病部 } & $13(6.2)$ & $11(4.1)$ & $3(2.0)$ & $6(1.5)$ & $8(1.1)$ & $41(2.4)$ \\
\hline 鎮 & \multirow{2}{*}{ 関 } & 郕 & $10(4.8)$ & $5(1.9)$ & $6(4.0)$ & $7(1.8)$ & $8(1.1)$ & $36(2.1)$ \\
\hline 額 & & 節 & $4(1.9)$ & $3(1.1)$ & $2(1.3)$ & $5(1.3)$ & $21(3.0)$ & $35(2.0)$ \\
\hline 唾 & \multicolumn{2}{|c|}{ 液・唾 液 } & $3(1.4)$ & $6(2.2)$ & $4(2.7)$ & $6(1.5)$ & $15(2.1)$ & $34(2.0)$ \\
\hline そ & の & 他 & $28(13.3)$ & $39(14.5)$ & $19(12.7)$ & $37(9.3)$ & $73(10.4)$ & $196(11.4)$ \\
\hline 論 & 女 & 数 & 210 & 269 & 150 & 396 & 699 & 1,724 \\
\hline
\end{tabular}

湯に関する論文が多く，また論文の占める割合が経年的 增加傾向にある主題は悪性腫瘍, 症候群・全身疾患, 顎 関節であった。これに対し，経年的減少傾向を示すすの は麻醉, 歯牙, 歯肉・歯周組織, 拔齿, 鎮痛郕であっ た. また抗生物質に関する論文は，その過半数が昭和 45 年から49年にかけて集中していることが知られる.

\section{考察}

主題分析の定義を，菊地 ${ }^{3)}$ は抄録や索引などを作るた めに記事の要点を抽出する作業としており，藤川4) は複 雑な内容を持つ主題を，その構成要素である重要概念に 分析し処理することとしている，また坂本 ${ }^{5)}$ は，文献が どのような主題から構成されているかを分析・表示する ことを主題分析といっている。 これらの定義からみる と, 主題分析の意義は, 主題分析によって得られた適切 な索引語をもちいて，より多くの情報のなかから，より 的確な論文を，より円滑に検索することにあるとい兄 る.しかしこれらの作業が人為的である以上，分析者の 主観が多分に加味される傾向がある。そのために論文の 利用者が 1 つの情報を分析者と同一の観点からみれば情 報検索に問題は生じないが，そらできない複雑な概念に ついて検索する場合には，混乱が生じることも考えられ
る.このような混乱を予防するためには，学術雜誌など の情報科学的分析をたえず行らことが望まれる．また分 析者は高度の知識背景を有している必要がある ${ }^{3)}$ と同時 に, 主題分析の過程を利用者に, 正確かつ適切に呈示し なければならない。

現在のわが国で，医学・歯学・薬学論文を活用するた めの 2 次資料として中心的役割を果たしているのは，医 学中央雑誌であると思われる．同誌に掲載された諭文数 は昭和 53 年 (昭和 52 年 12 月 5 日号 53 年 12 月 9 日号) 118,579 編， 54 年（53年 12 月 17 日号 54 年 12 月 13 日号） 136,149 編， 55 年 (54年12月 27 日号 55 年 12 月 17 日号) 142,585 編であり，そのうち歯学に属するすのは昭和 53 年 4,947 編，54年6,819編，55年 6,940 編である。 また収 載雑誌数は昭和55年 9 月 30 日現在で和文誌 1,467 , 欧文 誌 144 であり，わが国のこの領域での文献を網羅的に収 集しているといっている6)．乙かし同誌を利用者側から みれば，和文索引語は約 7,000 語あるが，それがあいら 党お順に羅列されているだけで分類表がないことや，口 腔科学関連の索引語が少ないなどの欠点があり, 同分野 での検索効率は悪い2)という．同誌に収録されている論 文などは，近年年間約15万件を越えようとしている( ${ }^{6}$ が， 現状のままで件数が増加することは，検索効率の増悪を 意味し, 利用者が適切な文献を得るには，より多くの時 


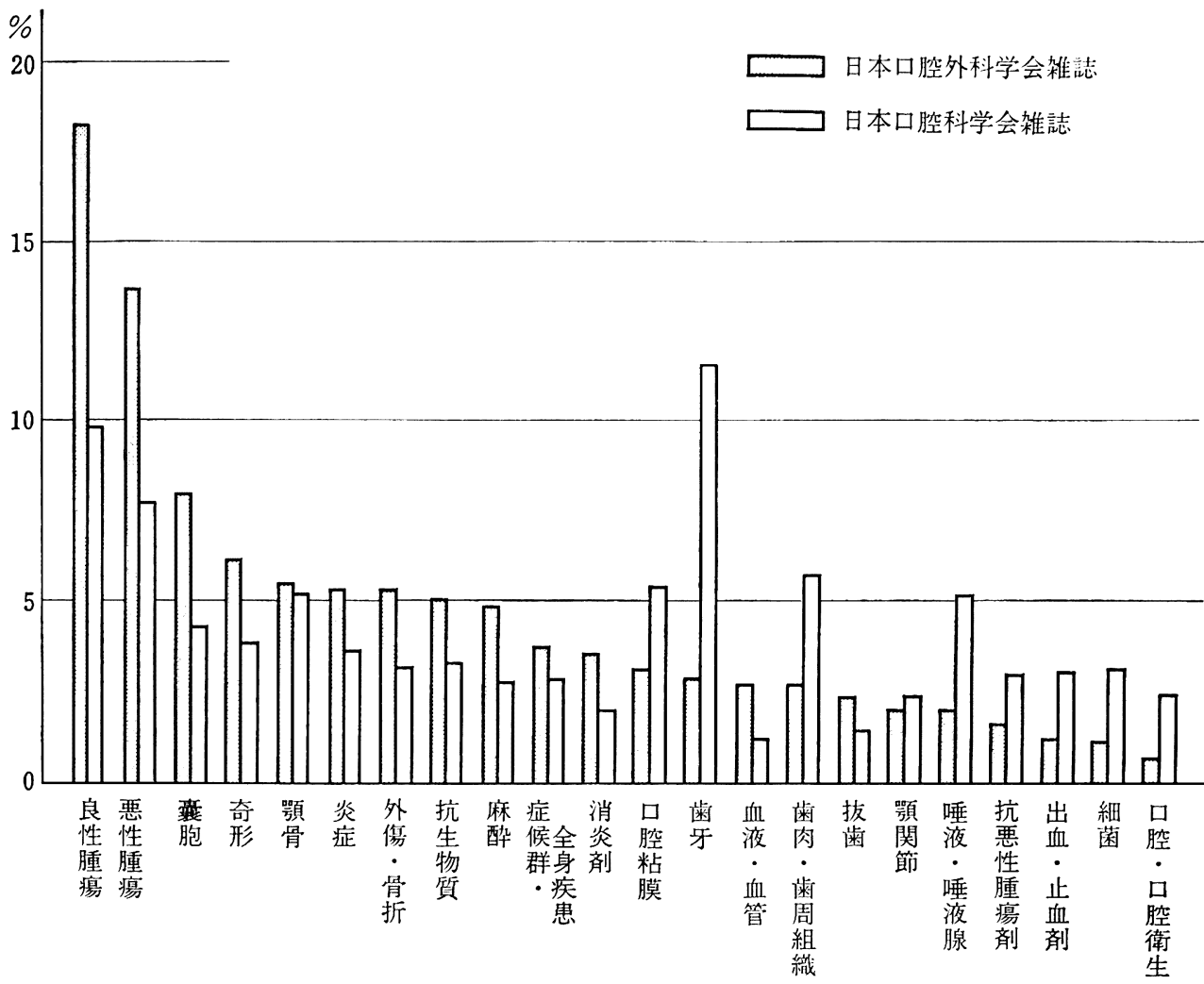

図 1 主要主題項目ことの論文の割合

間と労働が必要となってくる。このような事態を防ぐた めに, 待田 ${ }^{2)}$ のいらように索引語の組織だった細分化が 強く望まれ，その資料の一端とする目的で本研究が行わ れた。

今回の分析結果をみると, 主題項目と論文数の関係で は良性腫瘍, 悪性腫瘍, 垔胞などに関する口腔外科学的 論文が大部分を占めているのは当然といえるが，歯牙， 放射線, 細菌, 口腔・口腔衛生, 保存などの口腔外科学 的要因が少ないと思われる論文もわずか（101 編，5.9 \%)にみられた。 また，この結果を日本口腔科学会雑誌 のそれと比較すると，図1のごとくである，これより， 日本口腔外科学会雑誌では日本口腔科学会雑誌に比べて 良性腫汪，悪性腫瘍，露胞などの口腔外科学的論文の占 める割合が多いのに対し, 日本口腔科学 会雑誌では齿 牙，歯肉・歯周組織，唾液・唾液腺などに関するものが 多くなっている，また論文数が最多の項目は前者では良 性腫㾤, 後者では歯牙であることも両誌の特徵をあらわ しているといえよう。

各主題についての研究がどよらな方法で行われてい るか，どのようなーマであるかなどを知る目的で主要 主題項目を詳細に検討した。これによると全般的に症例
報告が非常に多い点が注目される。これは症例さえあれ ば，論文にまとめやすいためと考えられる。また抗生物 質についての論文はその大半が基礎的研究であるが，こ の理由の 1 つとて, 近年の抗生物質の開発製造に伴っ て，その効果と安全性を立証するために基礎的研究が多 くなったためと推测された，悪性腫瘍の論文では基礎的 研究が $21.4 \%$ とやや多いのは，その原因・成因が不明 で，しかも治療方針も確立されていないことなどから， 多角的な研究が遂行されていることを示している。また

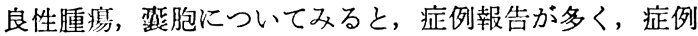
によっては多方面から報告されている観があり，今後は 観点を十分吟味しなければ症例報告の価値が見い出せな いといら䊝念がある。

主要主題に属する論文の年代変化では，各期間での諭 文数の合計は経年的增加傾向にあるが，昭和 $40 \sim 44$ 年に かけて減少しており，反対に昭和50〜 54年では急增して いる．急増している理由の 1 つとして，本研究の第 2 編 で述べるように7，近年の新増設された医科・歯科の大 学・学部による研究員の絶対数の増加によるものが考兄 られる。これは日本口腔科学会雑誌での論文数の推移 ${ }^{2}$ をみると，発表論文数の少ない機関による論文数の合計 
が，昭和49〜53年に増加していることと相通ずるものと 思われる. 昭和40〜44年にかけて論文数が減少している 理由は，当時激しかった大学紛争の影響も考光られる が，日本口腔科学会雑誌ではそのような傾向がみられ ず，その背景は不明である．主要主題の論文が各年代に おいて占める割合の変化をみると，時代を経るにつれて 増加するものは悪性腫瘍, 症候群・全身疾患, 顎関節な どであり，これに対して，麻酔，歯牙，歯肉・歯周組 織，拔歯，鎮痛剂等が減少している，それらの結果，日 本口腔外科学会雑誌の最近の主題は口腔外科学的なもの が大部分を占めるようになった．日本口貯科学会雑誌の 傾向も全く同じであり ${ }^{2}$, これら 2 雑誌が口腔外科学領 域でより専門的な雑誌になりつつあるすのと思われる.

今回の主題分析で, 日本口腔外科学会雑誌の特徵をあ る程度把握することができた。これらは雑誌などに主題 索引項目を設定する場合に重要な指針を与えるものであ る. 次の段階としては各論文に付すキーワードなどにつ いての検討が必要と思われる。このようにして得られた 結果を, 文献活用の面で論文利用者にフィードバックさ す方法の具体化は著者たちの能力以上のレベルで諭じら れる必要のある重要な問題である.

結論

口腔科学領域の学術論文を有効かつ円滑に活用する方 法を検討する目的の一環として, 日本口腔外科学会雑誌 の第 1 巻（昭和 30 年）から第 25 巻（昭和54年）までに掲 載された論文 1,724 編について主題分析をした。その結 果は下記のごとくであった。

1 ) 主題項目は, 口腔外科学を中心とした歯学全般の
31項目に分析できた。そのなかであ良性腫湯 (18.3\%), 悪性腫瘍 (13.6\%)，址胞 (7.9\%)，奇形 (6.2\%) に関 する論文が上位を占めた。

2 ）主要主題項目を詳細に検討すると，各主題とも症 例報告が多かった。

3）主要主題項目に属する論文の年代的変化をみる と, 最近増加の傾向を示すのは悪性腫瘍, 症候群・全身 疾患, 顎関節などであり麻酔, 歯牙, 歯肉・歯周組織, 抜歯，鎮痛凧などは減少している。

これらを基礎資料として文献活用をする時の問題点な ぞについても考察を加えた。

本論文の要旨は第25回日本口腔外科学会総会（徳島, 1980年）にて発表した。

\section{引用 文 献}

1）学術審議会：今後における学術情報システムの 在り方について (答申). 学術月報 $32: 724$ 1980.

2) 待田順治：口腔科学領域論交に関する情報科学 的研究。口科誌 30：549 1980 .

3）菊地敏典：主題分析。情報管理 9：460 1967.

4) 藤川正信 : 主題探索の基本問題. Library Science 1: 1071963.

5）坂本微朗：主題分析。情報管理 13：122 1970 .

6) 医学中央雑誌刊行会：医学中央雑誌（収㦲誌目 録). 東京, $1980, \mathrm{i} \sim \mathrm{iii}$ 頁

7) 林 清広, 他: 口腔外科学領域論文の情報科学 的分析 (2) 論文発表機関。日口外誌投稿中. 